\title{
Identifikasi Protozoa Usus pada Pasien yang Sedang Menjalani Kemoterapi di RSUP Dr M Djamil, Padang
}

\author{
Muhammad Marzain ${ }^{1}$, Eka Nofita ${ }^{2}$, Rima Semiarty $^{3}$
}

\begin{abstract}
Abstrak
Imunosupresi merupakan salah satu faktor risiko infeksi protozoa usus yang dapat terjadi pada pasien yang sedang menjalani kemoterapi. Tujuan penelitian ini adalah untuk mengidentifikasi protozoa usus pada pasien yang sedang menjalani kemoterapi di RSUP Dr M Djamil Padang. Penelitian ini menggunakan desain deskriptif dengan pengumpulan sampel sebanyak 33 tinja pasien secara consecutive sampling. Penelitian ini dilakukan di RSUP Dr M Djamil dari Juni 2017 hingga Maret 2018. Sampel diperiksa dengan menggunakan metode pemeriksaan tinja langsung dan dengan modifikasi pewarnaan Ziehl-Neelsen. Didapatkan angka infeksi protozoa usus sebesar 9,1\%, hanya spesies E. histolytica yang ditemukan. Semua sampel yang diperiksa merupakan single infection. Stadium tropozoit lebih banyak ditemukan yaitu sebesar $66,7 \%$. Protozoa usus hanya ditemukan pada kemoterapi siklus ke-2 $(66,7 \%)$ dan siklus ke-5 (33,3\%). Simpulan studi ini ialah masih ditemukan infeksi protozoa usus pada pasien yang sedang menjalani kemoterapi di RSUP Dr M Djamil, Padang, oleh karena itu terapi suportif dan pencegahan infeksi perlu dilakukan, sehingga angka kesakitan dapat dikurangi.
\end{abstract}

Kata kunci: protozoa usus, kemoterapi, E. histolytica

\begin{abstract}
Immunosupression is a risk factor of infection that could happen on patients with chemotherapy. The objective of this study was to identify intestinal protozoa in patients with chemotherapy in RSUP Dr M Djamil Padang. It is descriptive study was conducted in RSUP Dr M Djamil Padang from June 2017 until March 2018 to identify the protozoa in 33 feces samples that chosen by consecutive sampling technique. Samples were examined by direct fecal examination and modified Ziehl-Neelsen staining. The study showed that rate of infection by intestinal protozoa was $9.1 \%$ with only $E$. hystolitica species found. Every sample was having single infection. Trophozoite stadium was mostly found (66.7\%). Intestinal protozoa was found in second cycle of chemotherapy (66.7\%) and fifth cycle (33.3 $\%)$. The study concluded that there is intestinal protozoa infection in patients having chemotherapy in RSUP Dr M Djamil Padang. This study suggests for supportive therapy and infection prevention protocol to reduce the morbidity.
\end{abstract}

Keywords: intestinal protoza, chemotherapy, E. histolytica

Affiliasi penulis: 1. Prodi Kedokteran Fakultas Kedokteran Universitas Andalas Padang (FK Unand), 2. Bagian Parasitologi FK Unand, 3. Bagian IImu Kesehatan Masyarakat FK Unand Korespondensi: Muhammad Marzain, email: mrzmhd@gmail.com Telp: 081372391256

\section{PENDAHULUAN}

Infeksi protozoa usus merupakan salah satu masalah kesehatan di dunia terutama negara berkembang, dimana tingkat pendidikan yang rendah dan iklim tropis merupakan faktor risiko infeksi protozoa usus. Prevalensi yang tinggi umumnya ditemukan di lingkungan sosio-ekonomi rendah dan sanitasi yang buruk. Di Indonesia sendiri infeksi yang disebabkan oleh protozoa usus dapat ditemukan di daerah perkotaan ataupun daerah pedesaan. ${ }^{1}$

Spesies yang tergolong dalam protozoa usus yang mengakibatkan infeksi saluran pencernaan pada manusia yaitu berasal dari kelas Rhizopoda adalah 
Entamoeba histolytica, kelas Mastigophora adalah Giardia lamblia dan kelas Sporozoa adalah Blastocystis hominis. Entamoeba histolytica merupakan salah satu protozoa yang sering menjadi penyebab diare. $^{2}$

Infeksi protozoa usus dapat terjadi karena tertelannya makanan atau minuman yang terkontaminasi kista protozoa usus atau dengan transmisi langsung fecal-oral. Setelah tertelan, umumnya protozoa usus hidup sebagai patogen di usus halus dan usus besar, sehingga menimbulkan berbagai gejala seperti rasa tidak enak di perut, diare, muntah dan demam. Tidak semua infeksi protozoa menimbulkan gejala, beberapa orang dengan pemeriksaan feses positif protozoa usus tidak merasakan gejala sama sekali. $^{3}$

Cryptosporidium sp, Cyclospora cayetanensis, Isospora belli dan Blastocystis hominis adalah protozoa usus oportunistik yang sering ditemukan saat ini. Infeksi protozoa usus oportunistik ini dapat menimbulkan gejala yang bervariasi, mulai dari asimtomatik sampai diare berat persisten. Manifestasi klinis ini bergantung pada imunitas penderita. Pada pasien imunokompeten diare bersifat akut dan akan sembuh sendiri, tetapi gejala infeksi protozoa usus pada individu dengan imunosupresi lebih berat dan bisa mengancam jiwa. Hal ini dikarenakan peran sistem imun yang tidak mampu melawan infeksi parasit. ${ }^{4,5}$

Salah satu penyebab terjadinya imunosupresi adalah kanker dan terapi yang digunakan untuk mengobati kanker itu sendiri. Kanker merupakan salah satu penyebab kematian utama di seluruh dunia. Pada tahun 2012, ditemukan 14,1 juta kasus kanker baru, dengan 8,2 juta kematian akibat kanker dan 32,6 juta orang hidup dengan kanker di seluruh dunia. Di Indonesia sendiri berdasarkan penelitian yang dilakukan oleh Badan Penelitian dan Pengembangan Kesehatan, Kementrian Kesehatan RI tahun 2013, didapatkan angka kejadian kanker sebesar 1,4\%o atau sekitar 330.000 orang. Kanker merupakan penyebab kematian nomor 7 di Indonesia.,

Kanker dapat menurunkan sistem imun dan terapi yang digunakan untuk mengobati penyakit ini juga akan menyebabkan penurunan sistem imun. Ada beberapa jenis terapi yang diberikan kepada pasien. Secara umum terapi yang diberikan, yaitu terapi lokal dengan pembedahan dan radiasi, dan terapi sistemik. Terapi sistemik dilakukan dengan pemberian regimen kemoterapi yang bisa diberikan tunggal atau kombinasi. Prinsip dari pengobatan ini adalah untuk membunuh sel-sel neoplasma. Dalam penerapannya, obat kemoterapi ini tidak hanya menyerang sel-sel kanker, tetapi juga mengenai sel-sel yang normal, terutama sel yang berproliferasi secara cepat. ${ }^{4,8}$

Depresi sumsum tulang merupakan masalah terbesar dalam kemoterapi. Kebanyakan obat antitumor, kecuali hormon, bleomisin, L-asparaginase, semuanya menimbulkan leukopenia, trombositopenia dan anemia dengan derajat yang bervariasi. Depresi sumsum tulang yang parah dapat menyebabkan timbulnya infeksi, septikemia dan homoragi visera. Depresi sumsum tulang pada kemoterapi juga dapat menimbulkan efek mielosupresif, akibatnya pembentukan neutrofil akan terganggu yang akhirnya akan mengakibatkan neutropenia. Neutropenia adalah suatu kondisi dimana rendahnya jumlah neutrofil yang beredar di sirkulasi. $^{9,10}$

Berdasarkan penelitian yang dilakukan Neha Ballani et al di India, didapati 38 dari 100 pasien yang menjalani kemoterapi dan radioterapi untuk berbagai keganasan, ternyata mengalami infeksi protozoa usus. Cryptosporidium dan E. histolytica merupakan infeksi terbanyak (masing-masing 39,5\%), diikuti Giardia lamblia (13,2\%) dan Isospora belli (7,9\%). ${ }^{11}$

Penelitian lain yang dilakukan oleh AbdelMagied et al di Mesir, dari 145 pasien yang sedang menjalani terapi kanker (kemoterapi= 124 orang, radioterapi $=21$ orang) $85,5 \%$ pasien mengalami infeksi protozoa usus. Protozoa yang paling banyak ditemukan adalah Giardia lamblia 36,6\%, diikuti oleh Cryptosporidium parvum 30,3\%, Entamoeba histolytica $27,6 \%$, Blastocystis hominis $21,4 \%$, Entamoeba coli 11\%, Microsporidium 4,8\%, lodamoeba bütschlii 2,8\%, dan $H$. nana $1,45 \%$. Data tersebut terbagi menjadi single infection dan multiple infection. ${ }^{12}$

Diagnosis pasien yang terinfeksi protozoa perlu dilakukan pemeriksaan tinja dengan mendeteksi kista, trofozoit, ookista, bentuk granular, vakuolar, atau ameboid pada tinja. Beberapa spesies protozoa 
dapat dilihat secara langsung dibawah mikroskop. Namun untuk mempermudah identifikasi dapat dilakukan dengan pewarnaan salah satunya dengan teknik pewarnaan Ziehl-Neelsen. ${ }^{4}$

\section{METODE}

Desain penelitian ini adalah studi deskriptif. Pengumpulan sampel dilakukan di RSUP Dr M Djamil yang selanjutnya diperiksa di Laboratorium Parasitologi FK UNAND. Penelitian ini dari bulan Juni 2017 hingga maret 2018. Sampel pada penelitian ini adalah tinja pasien yang sedang menjalani kemoterapi di RSUP Dr M Djamil yang tidak memiliki riwayat imunosupresi sebelumnya. Sampel tinja yang terkumpulkan dilakukan pemeriksaan mikroskopis tinja dengan pemeriksaan tinja langsung dan dengan modifikasi pewarnaan Ziehl-Neelsen. Hasil yang didapatkan disajikan dalam bentuk distribusi frekuensi.

\section{HASIL}

Berdasarkan penelitian tentang pemeriksaan protozoa usus yang telah dilakukan di RSUP $\mathrm{Dr} M$ Djamil dan di Laboratorium Fakultas Kedokteran Universitas Andalas didapatkan hasil sebagai berikut.

Tabel 1. Angka kejadian infeksi protozoa usus

\begin{tabular}{lcc}
\hline $\begin{array}{l}\text { Kejadian Infeksi } \\
\text { Protozoa Usus }\end{array}$ & Frekuensi & $\begin{array}{c}\text { Persentase } \\
\text { (\%) }\end{array}$ \\
\hline $\begin{array}{lc}\text { Terinfeksi protozoa usus } \\
\text { Tidak terinfeksi protozoa }\end{array}$ & 3 & 9,1 \\
usus & 30 & 90,9 \\
\hline Total & 33 & 100 \\
\hline
\end{tabular}

Pada Tabel 1 terlihat sebanyak 3 orang pasien $(9,1 \%)$ terdapat protozoa usus pada pemeriksaan tinja.

Berdasarkan tabel 2 persentase responden laki-laki lebih banyak mengalami infeksi protozoa usus, yaitu $10 \%$ dari total 10 responden laki-laki. Infeksi protozoa usus ditemukan pada responden umur 21-30 tahun, 41-50 tahun dan $>60$ tahun.
Tabel 2. Distribusi Infeksi protozoa usus berdasarkan jenis kelamin dan umur

\begin{tabular}{|c|c|c|c|c|c|}
\hline \multirow[t]{2}{*}{$\begin{array}{l}\text { Karakteristik } \\
\text { Responden }\end{array}$} & \multicolumn{2}{|c|}{$\begin{array}{c}\text { Terinfeksi } \\
\text { Protozoa } \\
\text { Usus }\end{array}$} & \multicolumn{2}{|c|}{$\begin{array}{c}\text { Tidak } \\
\text { Terinfeksi } \\
\text { Protozoa } \\
\text { usus }\end{array}$} & \multirow[t]{2}{*}{$\begin{array}{c}\text { Total } \\
(\%)\end{array}$} \\
\hline & frek & $\%$ & frek & $\%$ & \\
\hline \multicolumn{6}{|l|}{ Jenis Kelamin } \\
\hline - laki-laki & 1 & 10,0 & 9 & 90,0 & 100 \\
\hline - perempuan & 2 & 8,7 & 21 & 91,3 & 100 \\
\hline \multicolumn{6}{|l|}{ Umur } \\
\hline $21-30$ & 1 & 20,0 & 4 & 80,0 & 100 \\
\hline $31-40$ & 0 & 0,0 & 5 & 100,0 & 100 \\
\hline $41-50$ & 1 & 11,1 & 8 & 88,9 & 100 \\
\hline $51-60$ & 0 & 0,0 & 7 & 100,0 & 100 \\
\hline$>60$ & 1 & 14,3 & 6 & 85,7 & 100 \\
\hline
\end{tabular}

Berdasarkan Tabel 3 dibawah ini dapat dilihat jenis protozoa usus yang ditemukan hanya Entamoeba histolytica.

Tabel 3. Distribusi frekuensi protozoa usus berdasarkan spesies protozoa usus

\begin{tabular}{lcc}
\hline \begin{tabular}{c} 
Spesies protozoa \\
\multicolumn{1}{c}{ usus }
\end{tabular} & Frekuensi & $\begin{array}{c}\text { Persentase } \\
(\%)\end{array}$ \\
\hline Giardia lamblia & 0 & 0 \\
E. histolytica & 3 & 100 \\
Balantidium coli & 0 & 0 \\
Isospora & 0 & 0 \\
Cryptosporidium & 0 & 0 \\
Cyclopora & 0 & 0 \\
Blastocystis & 0 & 0 \\
hominis & & 100 \\
\hline Total & 3 & \\
\hline
\end{tabular}

Distribusi Frekuensi Infeksi Protozoa Usus Berdasarkan Tipe Infeksi Protozoa Usus

Tabel 4. Distribusi frekuensi infeksi protozoa usus berdasarkan stadium parasit

\begin{tabular}{|c|c|c|}
\hline $\begin{array}{l}\text { Tipe Infeksi } \\
\text { Protozoa Usus }\end{array}$ & Frekuensi & $\begin{array}{c}\text { Persentase } \\
\text { (\%) }\end{array}$ \\
\hline Single Infection & 3 & 100 \\
\hline Mixed Infection & 0 & 0 \\
\hline Total & 3 & 100 \\
\hline
\end{tabular}


Berdasarkan Tabel 4, terlihat tipe infeksi yang ditemukan hanya single infection.

Tabel 5. Stadium protozoa usus

\begin{tabular}{llcc}
\hline Protozoa usus & Stadium & Frek & $\begin{array}{c}\text { Persentase } \\
\text { (\%) }\end{array}$ \\
\hline Giardia lamblia & Trofozoit & 0 & 0 \\
& Kista & 0 & 0 \\
E. histolytica & Trofozoit & 2 & 67 \\
& Kista & 1 & 33 \\
Balantidium coli & Trofozoit & 0 & 0 \\
Isospora & Kista & 0 & 0 \\
Cryptosporidium & Ookista & 0 & 0 \\
Cyclospora & Ookista & 0 & 0 \\
Blastocystis & Ookista & 0 & 0 \\
hominis & Vakuolar & 0 & 0 \\
& Ameboid & 0 & 0 \\
& Granular & 0 & 0 \\
& Kista & 0 & 0 \\
\hline Total & & 3 & 100 \\
\hline
\end{tabular}

Berdasarkan Tabel 5 stadium protozoa paling banyak ditemukan yaitu stadium trofozoit sebanyak 2 sampel $(66,7 \%)$.

Tabel 6. Distribusi frekuensi protozoa usus berdasarkan siklus kemoterapi

\begin{tabular}{cccccc}
\hline Sikus & \multicolumn{3}{c}{ Protozoa Usus } & \multicolumn{2}{c}{ Total } \\
\cline { 2 - 5 } Kemoterapi & Positif & $\%$ & Negatif & $\%$ & \\
\hline I & 0 & 0 & 10 & 30,3 & 10 \\
II & 2 & 6,1 & 10 & 30,3 & 12 \\
III & 0 & 0 & 1 & 3,0 & 1 \\
IV & 0 & 0 & 2 & 6,1 & 2 \\
V & 1 & 3,0 & 4 & 12,1 & 5 \\
VI & 0 & 0 & 3 & 9,1 & 3 \\
\hline Total & 3 & 9,1 & 30 & 90,9 & 33 \\
\hline
\end{tabular}

Berdasarkan Tabel 6 protozoa usus paling banyak ditemukan pada pasien yang sedang menjalani kemoterapi siklus ke-2 yaitu 2 sampel $(6,1 \%)$.

\section{PEMBAHASAN}

Pada penelitian yang telah dilakukan pada pasien kanker yang sedang menjalani kemoterapi di RSUP Dr M Djamil, Padang yang berjumlah 33 orang, ditemukan protozoa usus pada 3 sampel $(9,1 \%)$ dari tinja yang diperiksa. Hasil ini tidak jauh berbeda dengan penelitian yang telah dilakukan oleh Kaleiselvam pada pasien kanker yang menjalani kemoterapi di RSUP H Adam Malik Medan yaitu ditemukan $7,9 \%$ pasien ditemukan protozoa usus pada sampel tinja yang diperiksa. Prevalensi ini jauh lebih rendah dibandingkan dengan penelitian yang dilakukan oleh Neha Ballani et al di India yaitu ditemukan 38 dari 100 (38\%) pasien kanker yang menjalani kemoterapi dan radioterapi ditemukan protozoa usus pada pemeriksaan tinjanya. Adanya perbedaan dari berbagai penelitian ini dapat disebabkan oleh beberapa faktor diantaranya karakteristik sampel yang digunakan, faktor lingkungan dan personal hygiene, stadium kanker, serta kualitas hidup pasien. ${ }^{11,13}$

Berdasarkan jenis kelamin, angka kejadian infeksi protozoa usus lebih tinggi pada perempuan $(6,1 \%)$ dibanding laki-laki (3\%). Kecenderungan terjadinya infeksi protozoa usus pada seseorang dipengaruhi oleh status gizi, umur, hygiene perorangan, sanitasi lingkungan sekitar, keadaan sosial ekonomi, serta adanya komplikasi dengan infeksi parasite atau bakteri lain. Jadi, infeksi protozoa usus ini tidak dipengaruhi oleh jenis kelamin. Tingginya infeksi protozoa usus yang terjadi pada perempuan pada penelitian ini mungkin terjadi karena jumlah responden perempuan lebih banyak dari pada laki-laki. Dengan semakin banyak sampel, probabilitas untuk ditemukan protozoa usus pada pemeriksaan tinja akan semakin besar. ${ }^{14,15}$

Jenis protozoa yang ditemukan hanya spesies Entamoeba histolytica, yaitu 3 dari 33 (9,1\%) sampel yang diperiksa ditemukan spesies Entamoeba histolytica. Hal ini berbeda dengan penelitian yang dilakukan oleh Uysal et al, yaitu Cryptosporidium merupakan protozoa yang paling banyak ditemukan yaitu $69,2 \%$ dari total sampel yang mengandung protozoa usus. Penelitian serupa yang dilakukan oleh Neha Ballani et al di India, ditemukan Cryptosporidium dan $E$. histolytica merupakan protozoa usus terbanyak (masing-masing 39,5\%) yang ditemukan pada pasien kanker yang sedang menjalani kemoterapi. Adanya Perbedaan pada penelitian ini dapat disebabkan oleh 
beberapa faktor seperti keadaan geografis, sanitasi lingkungan, kebiasaan (PHBS), sosio-ekonomi yang rendah, umur, status gizi, serta keadaan imun seseorang. ${ }^{11,16}$

Pada tiga sampel yang ditemukan protozoa usus, semuanya berupa single infection. Hasil yang sama juga didapatkan pada penelitian yang dilakukan Kaleiselvam di RSUP $\mathrm{H}$ Adam Malik Medan. Berdasarkan penelitian yang dilakukan Abdel-Magied et al di Mesir didapatkan hasil yang berbeda, yaitu $49,2 \%$ infeksi protozoa usus bersifat multiple infection. Tingginya angka kejadian multiple infection pada penelitian Abdel-Magied et al ini dikarenakan sampel yang digunakan adalah pasien yang sedang menjalani terapi kanker dengan diare, sedangkan penelitian yang dilakukan di RSUP Dr M Djamil ini tidak memandang pasien mengalami diare atau tidak. ${ }^{12,13}$

Pada penelitian ini ditemukan E. histolytica stadium trofozoit dan stadium kista. Stadium trofozoit lebih banyak ditemukan (67\%), sedangkan stadium kista ditemukan 33\%. Pada penelitian ini, berdasarkan pemeriksaan makroskopis tinja, dinyatakan positif adanya trofozoit E. histolytica memiliki konsistensi yang encer dan berlendir, tetapi tinja yang terdapat kista E. histolytica memiliki konsistensi yang lebih padat. Hal ini sesuai dengan yang telah dijelaskan sebelumnya bahwa gejala infeksi (diare) biasanya terjadi pada stadium trofozoit, sedangkan stadium kista bersifat carier dan biasanya tanpa ada gejala. ${ }^{4}$

Pada segi umur, stadium trofozoit yang ditemukan pada penelitian ini ditemukan pada pasien yang berumur lebih dari 40 tahun. Hal ini akan mengakibatkan gejala yang lebih berat, mengingat seiring dengan meningkatnya usia kemampuan imunitas akan semakin menurun termasuk respon melawan infeksi. Adanya penurunan kemampuan imunitas ini, ditambah dengan pemberian kemoterapi hal ini tentu akan semakin menekan sistem imun. Dengan demikian adanya infeksi protozoa usus memungkin terjadinya gejala yang lebih berat. ${ }^{17}$

Pada penelitian ini infeksi protozoa usus hanya ditemukan pada pasien yang sedang menjalani kemoterapi siklus ke-2 dan ke-5. Angka kejadian infeksi lebih tinggi pada pasien yang sedang menjalani kemoterapi siklus ke-2 (67\%) daripada pasien yang sedang menjalani kemoterapi siklus ke-5. Distribusi yang tidak merata ini bisa disebabkan berbagai faktor, seperti faktor lingkungan, keadaan umum, nutrisi, dan respon yang berbeda pada tiap pasien. Syarat seorang pasien untuk mendapatkan kemoterapi, seperti keadaan umum cukup baik, $\mathrm{Hb}>10 \mathrm{gram} / \mathrm{dl}$, leukosit > $5000 / \mathrm{mm}^{3}$, trombosit $>150.000 / \mathrm{mm}^{3}$ memungkinkan daya tahan tubuh yang kuat untuk melawan infeksi. ${ }^{18}$

\section{SIMPULAN}

Protozoa yang ditemukan hanya spesies $E$. histolytica stadium trofozoit dan kista.

\section{DAFTAR PUSTAKA}

1. Anorital, Dewi RM, Ompusunggu S. Distribusi parasit usus protozoa di Kabupaten Hulu Sungai Utara Kalimantan Selatan. Suplemen Media Penelit dan Pengemb Kesehat. 2010;20:8-18.

2. Garcia LS, editor (penyunting). Diagnostic medical parasitology. Edisi ke-5. ASM Press; 2007.

3. Osman M, Elsafadi D, Cian A, Benamrouz S, Nourrison $\mathrm{C}$, Poirier $\mathrm{P}$, et al. Prevalence and risk factors for intestinal protozoan infections with Cryptosporidium, Giardia, Blastocystis and Dientamoeba among school children in Tripoli, Lebanon. PLoS Negl Trop Dis. 2016;10(3):1-2.

4. Susanto L, Gandahusada S. Coccidia. Dalam: Susanto I, Ismid IS, Sjarifuddin PK, Sungkar S, editor (penyunting). Parasitologi Kedokteran. Edisi ke-4. Jakarta: Balai Penerbit FKUI; 2008.hlm.158-79.

5. Sears CL, Kirkpatrick BD. Cryptosporidiosis and isosporiasis. Dalam: Gillespie $\mathrm{SH}$, Pearson RD, editor (penyunting). Principles and Practice of clinical parasitology. New York; 2001.hlm.13959.

6. American Cancer Society. The Global fight against cancer. Dalam: Global Cancer facts and figures. Edisi ke-3. Atlanta: American Cancer Society; 2015.hlm.52-3.

7. Kementerian Kesehatan RI (Kemenkes RI). Mediakom Kanker, pembunuh papan atas. Kemenkes RI; 2015.hlm.10-1. 
8. Greaves M. Speculation on the cause of childhood acute lymphoblastic leukemia. Dalam: Permono B, Sutaryo, Ugrasena I, Windiastuti E AM, editor penterjemah. Hematologi onkologi anak. Edisi ke-2. Jakarta: Badan Penerbit IDAI; 2006.hlm. 236-7.

9. Desen W. Buku Ajar onkologi klinis. Edisi ke-2. Jakarta: Balai Penerbit Fakultas Kedokteran Universitas Indonesia; 2008.hlm.150-8.

10. Jong $W$ De. Buku ajar ilmu bedah. Edisi ke-2. Sjamsuhidajat $\mathrm{R}$, editor penterjemah. Jakarta: EGC; 2005.hlm. 387-402.

11. Ballani N, Shujatullah F, Kan HM, Malik A, Ali MAS., Khan PA. Intestinal protozoa in immunosuppression: a medical hassle. J Bacteriol Parasitol. 2012;3(3):1-5.

12. Abdel-Magied AA, El-Ghanam WA, El-Nemr HI, El-Henawy AA. Prevalence of intestinal parasites in cancer therapy recipients with concurrent diarrhea. Int J Trop Dis Heal. 2016;15(1):1-7.

13. Kaleiselvam R. Prevalensi infeksi protozoa usus pada pasien kanker di RSUP Haji Adam Malik
Medan (skripsi). Medan: Universitas Sumatera Utara: 2010

14. Nurhayati. Gambaran infeksi protozoa intestinal pada anak binaan rumah singgah Amanah Kota Padang. Maj Kedokt Andalas. 2010;34(1):52-8.

15. Notoadmodjo S. Metodologi penelitian kesehatan. Edisi ke-3. Jakarta: Rineka Cipta; 2005.hlm. 68-70.

16. Uysal S, Tunali V, Ardenis O, M IT, Pullukcu H, Turgay N. Incidence of parasitic diarrhea in patients with common variable immune deficiency. Turkiye Parazitol Derg. 2016; 40(2): 67-71.

17. Fatmah. Respon imunitas yang rendah pada tubuh manusia usia lanjut. Makara Kesehat. 2006;10(1):47-53.

18. Neuss MN, Gilmore TR, Belderson KM, Billett AL, Conti-Kalchik T, Harvey BE, et al. 2016 Updated American society of clinical oncology nursing society chemotherapy administration safety standards, including standards for pediatric oncology. Oncol Nurs Forum. 2016;44(1):1-10. 